\title{
Effects of the Foliar Application of Magnesium and Zinc on the Yield and Quality of Three Grape Cultivars Grown in the Calcareous Soils of Iran
}

\author{
Ahmad BYBORDI, Jasarat A. SHABANOV \\ Baku State University, Soil Science Department, 23 Z. Khalilov Street, 370148 Baku, Azerbaijan; abaybordy@yahoo.com,jasarat@mail.ru
}

\begin{abstract}
A completely randomized factorial block designed experiment was carried out at Maragheh region during 2007-2008 to evaluate the effects of the foliar applications of magnesium $(\mathrm{Mg})$ and zinc $(\mathrm{Zn})$ on the yield and quality of three grape cultivars. Factor one included three levels of $\mathrm{Mg}\left(0,0.40\right.$ and $\left.0.80 \% \mathrm{MgSO}_{4} \times \mathrm{H}_{2} \mathrm{O}\right)$; Factor two consisted of three levels of $\mathrm{Zn}\left(0,0.20\right.$ and $\left.0.40 \% \mathrm{ZnSO}_{4} .7 \mathrm{H}_{2} \mathrm{O}\right)$; and factor three involved three cultivars of grape (Vitis vinifera L.) namely 'Sahebi', 'Soltani' and 'Ghezel'. The foliar applications were carried out in two stages, namely, during the enlargement of flower buds and three weeks after the flower petals dropped (late spring). Yield and quality characteristics such as total soluble solids (TSS), juice, $\mathrm{pH}$ and acidity were determined. The statistical analyses were performed using MSTATC software and Duncan tests. The analysis of variance demonstrated that the main effects of $\mathrm{Mg}$, $\mathrm{Zn}$ and cultivars on yield were statistically significant at $1 \%$ level; and the interactive effects of the foliar application of $\mathrm{Mg}$ and $\mathrm{Zn}$ on the yield were significant at $5 \%$ level. The highest yield was obtained with the combined foliar applications of $\mathrm{Mg}$ and Zn-fertilizers. 'Ghezel' variety produced the highest yield of 47.11 tons ha ${ }^{-1}$ among the three cultivars. The main effects of $\mathrm{Mg}$ and $\mathrm{Zn}$ foliar application as well as of cultivars were significant. TSS contents were significant at $1 \%$ level. The highest $\mathrm{pH}$ values were obtained with the foliar application of $\mathrm{Mg}$ sulfate at $0.80 \%$ and $\mathrm{Zn}$ sulfate at $0.40 \%$. Likewise, the main effects of foliar application of $\mathrm{Mg}$ and $\mathrm{Zn}$ were significant at $1 \%$ level in the lowering of juice acidity and $\mathrm{K} / \mathrm{Mg}$ ratio. Foliar application did not decrease the $\mathrm{K} / \mathrm{Mg}$ ratio to the desirable level, however in the deficient soils, foliar application was not enough. It means in additional of foliar application, soil application is also necessary for obtaining desirable grape yield and quality.
\end{abstract}

Keywords: grape (Vitis vinifera L.) cultivars, yield, quality, $\mathrm{K} / \mathrm{Mg}$ ratio

\section{Introduction}

Vineyard soils in Iran are primarily calcareous, with a pH above 7.8 and organic matter (OM) of less than $1.00 \%$, and TNV exceeding $10.0 \%$. The overuse of P-fertilizers with $\mathrm{P}$ accumulation in soils reduces the availability of the other nutrients below the critical demands in vineyards where the grapes have performed poorly due to the resulting poor uptakes of nutrients, especially magnesium $(\mathrm{Mg})$ and zinc $(\mathrm{Zn})$ (Malakouti et al., 2005). Another problem is the poor management and concern over the quality of the irrigation water. Bicarbonate contents of irrigation waters, especially those of the well waters, are at high levels (Mengel and Kirkby; 1987 Shahabi et al., 2005).

$\mathrm{Mg}$ is absorbed by plants as $\mathrm{Mg}$ and the amounts of its absorption depend on the available $\mathrm{Mg}$, Soil $\mathrm{pH}$, CEC, $\% \mathrm{Mg}$ saturation on the CEC and available $\mathrm{K}$ and $\mathrm{Ca} . \mathrm{Mg}$ concentration in grape is about $0.60 \%$. The quantity of $\mathrm{Mg}$ taken up by plants is usually less than that of Ca or K. Mg is a primary constituent of chlorophyll, and without chlorophyll photosynthesis would not occur. $\mathrm{Mg}$ in chlorophyll accounts for 15 to $20 \%$ of the total $\mathrm{Mg}$ content of plants. $\mathrm{Mg}$ also serves as a structural component in ribosome granules, stabilizing them in the configuration necessary for protein synthesis. $\mathrm{Mg}$ critical level in the arable soils of vineyards is around $750 \mathrm{mg} \mathrm{kg}^{-1}$ according to the ammonium acetate extractant (Malakouti and Rezaei, 2001). It has been observed that growth depressions and visible $\mathrm{Mg}$ deficiency symptoms occur if the $\mathrm{Mg}$ in the chlorophyll exceeds $20-25 \%$ of the total Mg content in plants (Mengel and Kirkby, 1987). This means that through this "inactivation" other metabolic processes which require $\mathrm{Mg}$, including the formation of chloroplasts, is retarded or cannot fully operate. Besides being an integral part of the chlorophyll, $\mathrm{Mg}$ is involved in the carboxylase reaction of the photosynthesis, namely, as a coenzyme in the fixation of $\mathrm{CO}_{2}$. During the $\mathrm{CO}_{2}$ assimilation, sugar molecules are formed from water and carbon dioxide utilizing solar energy. This is the basic reaction for the synthesis of other plant constituents such as starch, proteins, fat and vitamins. In the case of a low $\mathrm{Mg}$ supply in the leaves, $\mathrm{CO}_{2}$ fixation is severely inhibited. As a charged divalent cation, $\mathrm{Mg}$ is involved in the cation-anion balance, where it is responsible for $\mathrm{pH}$ regulation and turgor adjustment of plant cells. About five percent of the $\mathrm{Mg}$ is bound to pectate and serves as a structural element of cell walls. The remaining $\mathrm{Mg}$, which is not fixed to structures such as chlorophyll and cell wall, is highly mobile, and it is estimated that about $20 \%$ of 
82

all the $\mathrm{Mg}$ which has been taken up circulates within the vascular system of xylem and phloem. Because of its high mobility in the phloem, $\mathrm{Mg}$ is easily re-translocated from older leaves to places of intensive metabolic activity. This is the reason why visual $\mathrm{Mg}$ deficiency symptoms always occur first on the older leaves (Kali, 2002). Leaching of $\mathrm{Mg}$ is often a severe problem ( $35 \mathrm{~kg}$ per ha per year) and its deficiency occurs in the northwestern soils of Iran, which are under the cultivation of grape and where high rates of $\mathrm{NH}_{4}$ or K-fertilizers are applied (Havlin et al., 2005). $\mathrm{Mg}$ is important as a cofactor in most enzyme activating phosphorylation processes, bridging ATP or ADP and the enzyme. These Mg ATP complexes are required in energy transfer processes, e.g. during the synthesis of starch, which is impaired if $\mathrm{Mg}$ is in low supply. On the other hand, $\mathrm{Mg}$ deficiency also inhibits the degradation of starch in source (older) leaves, which serves as a main energy source in the sinks (growing tissue, storage organs). Since $\mathrm{Mg}$ is also involved in the loading and unloading of the phloem through $\mathrm{Mg}$ dependent membrane-bound ATP ases, both the mobilization and the transportation of carbohydrates to places of high demand are inhibited if the $\mathrm{Mg}$ status of the plant is inadequate. This explains why, under Mg deficiency, partitioning of carbohydrates within the plants is dramatically shifted to the disadvantage of the roots. These $\mathrm{Mg}$ triggered membrane bound ion pumps are also essential for the uptake of nutrients by root cells. Under $\mathrm{Mg}$ deficiency, protein $\mathrm{N}$ decreases while non-protein $\mathrm{N}$ generally increases in plants. $\mathrm{Mg}$ is associated with transfer reactions involving phosphate reactive groups and also is required for maximal activity of almost every phosphorylating enzyme in carbohydrate metabolism. Most reactions involving phosphate transfer from adenosine triphosphate (ATP) require Mg. Since the fundamental process of energy transfer occurs in photosynthesis, glycolysis, the citric acid or Krebs cycle, and respiration, $\mathrm{Mg}$ is important throughout plant metabolism (Havlin et al., 2005).

$\mathrm{Zn}$ deficiency is widespread in plants and human beings in many countries due to the calcareous nature of soils, high $\mathrm{pH}$, low $\mathrm{OM}$, salt stress, continual droughts, high temperature, high bicarbonates in irrigation water, e.g. irrigation water with $\mathrm{HCO}_{3}{ }^{-}$concentration of four meq $\mathrm{l}^{-1}=$ $244 \mathrm{mg} \mathrm{l}^{-1}$ added to a field crop or an orchard at a rate of 5000 $\mathrm{m}^{3}$ per hectare per year, the amount of added $\mathrm{HCO}_{3}$ to soil will exceed one ton per hectare per year (about $1220 \mathrm{~kg} \mathrm{ha}^{-1}$ ), and overuse of P-fertilizers and imbalanced application of fertilizers (Malakouti, 2007). $\mathrm{Zn}$ is one of the essential elements for plants, and humans, but it is deficient (less than $1.00 \mathrm{mg} \mathrm{kg}^{-1}$ DTPA-extractable $\mathrm{Zn}$ ) in most calcareous soils and, consequently, in plant and human diets. $\mathrm{Zn}$ functions in plants in important ways. It is first of all a component of molecular structure of enzymes, besides being a co-factor in regulating the reactions of many enzymes. It is found as a part of at least four enzymes, including carbonic anhydrase, alcohol dehydrogenase, superoxide desmotase, and RNA polymerase. The enzymes that are known to be activated by $\mathrm{Zn}$ include dehydrogenase, aldoholase, isomerase, transphosphorilase, RNA and DNA polymerase. Zn participates in the plant metabolic processes of protein and carbohydrate transformations. Zn deficiency quickly reduces the rate of activities of carbonic anhydrase. The normal functions of this enzyme accumulating in cytoplasm and chloroplasm include fixation of $\mathrm{CO}_{2}$ in the photosynthetic processes. $\mathrm{Zn}$ also plays a part in the plant nitrogen metabolism. The first possible effect of $Z n$ deficiency would be seen as the reduced levels of RNA cell and ribosome, which in turn halt protein synthesis, leading to the accumulation of free amino acids. $\mathrm{Zn}$ is essential for the formation of indole acetic acid (IAA) from triptophane, one of the necessary ingredients for the synthesis of IAA. This growth factor (IAA) would be indirectly affected by $\mathrm{Zn}$ concentrations. High levels of triptophane in plant leaves low in $\mathrm{Zn}$ are possibly due to this synthetic process which is slowed down. The activity of alcohol dehydrogenase (ADH) would be severely reduced due to low $\mathrm{Zn}$ levels. This enzyme plays a very important part in the root metabolic activities under stress anaerobic conditions where acetaldehyde is reduced to ethanol. Therefore, under $\mathrm{Zn}$ deficiency situation, metabolic activities of anaerobic roots will be disturbed (even under aerobic conditions, formation of ethanol will take place mostly in the meristematic tissue at the tip of the roots). Zn also affects the metabolic reactions of gibberellic acid, whereby such reactions are disturbed under $\mathrm{Zn}$ deficiency conditions (Marschner, 1995).

Application of $\mathrm{Zn}$-fertilizers under $\mathrm{Zn}$ deficiency conditions has been associated with improved yield and quality of grapes (Malakouti, 2007). Malakouti (2006) in an extensive investigation and analyzing more than 1000 soil and leaf samples of vineyards under different management systems during the past decade (1995-2004) found that in $\mathrm{Zn}$ deficient calcareous soils foliar application of $\mathrm{Zn}$ improved yield and quality of grapes. He found that the desirable $\mathrm{Mg}$ and $\mathrm{Zn}$ concentrations, respectively, for grape leaves were 0.60 percent and $35 \mathrm{mg} \mathrm{kg}^{-1}$, for fresh grapes were 10 and $0.10 \mathrm{mg} \mathrm{kg}^{-1}$ and for raisins were 16 and 0.20 $\mathrm{mg} \mathrm{kg}{ }^{-1}$. He concluded that $\mathrm{Mg}$ and $\mathrm{Zn}$ deficiencies exist among vineyards (Malakouti, 2006).

In the fertilization practices in the calcareous soils of Iran, $\mathrm{Mg}$ has rarely received the same attention as $\mathrm{N}, \mathrm{P}$ and $\mathrm{K}$. Application of magnesium sulphate to grapes usually increases the sugar content of the grape. This is the main reason why French grape growers use a lot of magnesium sulphate. Despite abundant amounts of $\mathrm{Mg}$ in the parent materials of calcareous soils, hidden Mg deficiency exists in grapes. The main reasons for this hidden hunger are the overuse of K-fertilizers and high available Ca. The experimental results revealed that $\mathrm{K} / \mathrm{Mg}$ ratio is very important for grape quality. An appropriate amount of $\mathrm{K} / \mathrm{Mg}$ ratio (5.0-7.0) is needed for better grape quality (Malakouti and Rezaei, 2001). Although high levels of K nutrition depress Mg uptake due to a preferential K uptake by plants, increasing K supply affects the $\mathrm{Mg}$ content of various plant organs 
to varying degrees (Kali, 2002). Moreover, the negative effects of $\mathrm{K}$ on the $\mathrm{Mg}$ status and yield seem to be confined to the deficiency range of $\mathrm{Mg}$ supplied. Increasing $\mathrm{K}$ application does not affect grain yields as long as Mg levels in the plant tissue do not fall below the critical threshold values. This shows the importance of an adequate and balanced supply of both nutrients. Kali (2002) reported that along with the application of K-fertilizer, applying magnesium sulphate was fruitful in grape sugar content. Due to the existence of the incompatibility of prices between subsidized $\mathrm{N}, \mathrm{P}, \mathrm{K}$-fertilizers and unsubsidized $\mathrm{Mg}$ and $\mathrm{Zn}$-fertilizers, this study was to investigate the foliar application of $\mathrm{Mg}$ and $\mathrm{Zn}$ sulphates on the yield and quality of three grape cultivars in Azarbyjan province where the soils usually suffer from $\mathrm{Mg}$ and $\mathrm{Zn}$ deficiencies.

\section{Materials and methods}

A completely randomized factorial block designed experiment was carried out at Maragheh region during 2007-2008 to evaluate the effects of foliar applications of $\mathrm{Mg}$ and $\mathrm{Zn}$ on the yield and quality of three grape cultivars. Factor one included three levels of $\operatorname{Mg}(0,0.40$ and $0.80 \% \mathrm{MgSO}_{4} \times \mathrm{H}_{2} \mathrm{O}$ ); Factor two consisted of three levels of $\mathrm{Zn}\left(0,0.20\right.$ and $\left.0.40 \% \mathrm{ZnSO}_{4} .7 \mathrm{H}_{2} \mathrm{O}\right)$; and factor three involved three cultivars of grape (Vitis vinifera L.), namely, 'Sahebi,' 'Soltani' and 'Ghezel'. The foliar applications were carried out in two stages, namely, during the enlargement of flower buds and three weeks after the flower petals dropped (late Spring). Other nutrients were applied uniformly for all the treatments on the basis of soil tests. Yield and quality characteristics such as total soluble solids (TSS), juice, $\mathrm{pH}$ and acidity were determined. The statistical analyses were performed using MSTATC software and Duncan test.

\section{Results and discussion}

Results of the soil, water and leaf analyses are shown in Tab. 1, 2 and 3. The experimental data showed that the fertilizer treatments significantly affected the nutrient concentrations in leaves and consequently in dried fruits. There were significant differences in the concentrations of $\mathrm{Mg}$ and $\mathrm{Zn}$ in grape leaves and grape fruits, mainly due to the foliar application of $\mathrm{Mg}$ and $\mathrm{Zn}$-fertilizers (Tab. 3 and 4). The analysis of variance showed that the main effects of $\mathrm{Mg}, \mathrm{Zn}$ and cultivars on yield were statistically significant at $1 \%$ level and the interactive effects of the foliar application of $\mathrm{Mg}$ and $\mathrm{Zn}$ on the yield were significant at $5 \%$ level. The highest yield ( 47.11 tons ha ${ }^{-1}$ ) was obtained with the combined applications of $\mathrm{Mg}$ and $\mathrm{Zn}$ (Fig. 1). 'Ghezel' variety produced the highest yield of 47.11 tons ha ${ }^{-1}$ among the three cultivars. The main effects of $\mathrm{Mg}$ and $\mathrm{Zn}$ applica-

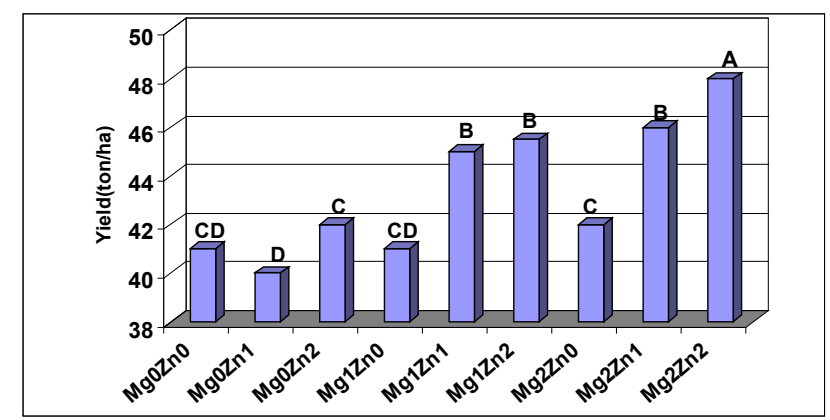

Fig. 1. Effects of foliar application of $\mathrm{Mg}$ and $\mathrm{Zn}$ on the yield of grapes

tions as well as of cultivars were significant. TSS contents were significant at $1 \%$ level. The highest TSS level (15.4\%)

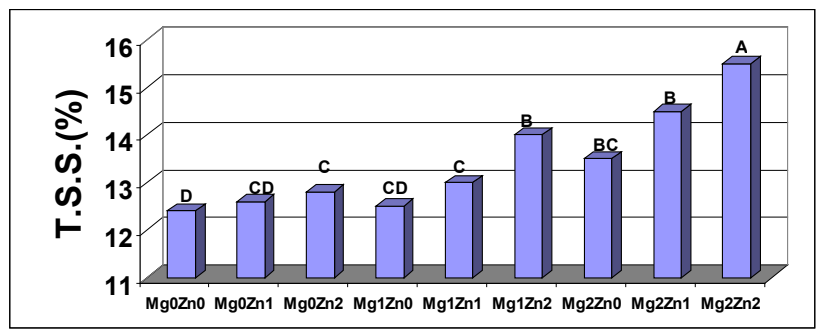

Fig. 2. Effects of foliar application of $\mathrm{Mg}$ and $\mathrm{Zn}$ on TSS of grapes

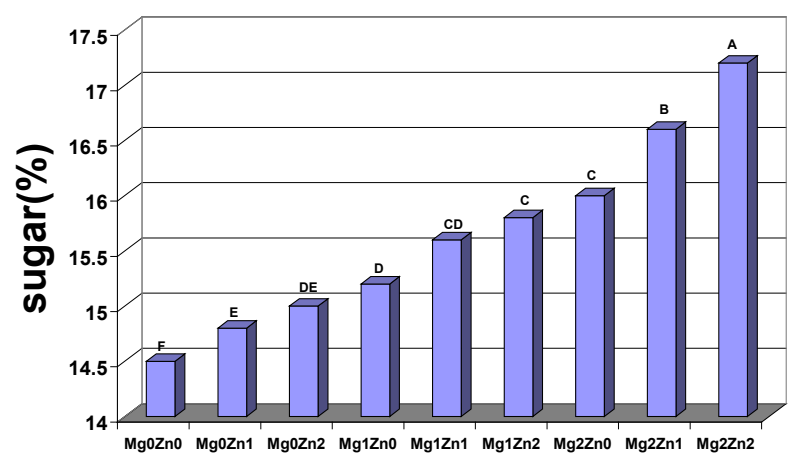

Fig. 3. Effects of $\mathrm{Mg}$ and $\mathrm{Zn}$ on the sugar percentage in grapes

Tab. 1. Chemical and physical characteristics of the studied soil

\begin{tabular}{ccccccccccccc}
\hline $\begin{array}{c}\mathrm{Fe} \\
\mathrm{mg} \mathrm{kg}^{-1}\end{array}$ & $\begin{array}{c}\mathrm{Zn} \\
\mathrm{mg} \mathrm{kg}\end{array}$ & $\begin{array}{c}\mathrm{Mg} \\
\mathrm{mg} \mathrm{kg}^{-1}\end{array}$ & $\begin{array}{c}\mathrm{OC} \\
\%\end{array}$ & $\begin{array}{c}\text { Clay } \\
\%\end{array}$ & $\begin{array}{c}\text { Silt } \\
\%\end{array}$ & $\begin{array}{c}\text { Sand } \\
\%\end{array}$ & $\begin{array}{c}\mathrm{P} \\
\mathrm{mg} \mathrm{kg}^{-1}\end{array}$ & $\begin{array}{c}\mathrm{K} \\
\mathrm{mg} \mathrm{kg}^{-1}\end{array}$ & T.N.V.\% & $\mathrm{pH}$ & $\begin{array}{c}\text { EC } \\
\mathrm{dS} / \mathrm{m}\end{array}$ & $\begin{array}{c}\text { Depth } \\
\mathrm{Cm}\end{array}$ \\
\hline 4.60 & 0.35 & 40 & 0.56 & 38 & 26 & 36 & 6.5 & 160 & 14 & 7.9 & 1.4 & $0-30$ \\
3.20 & 0.22 & 30 & 0.41 & 36 & 24 & 36 & 4.2 & 120 & 15 & 8.1 & 1.7 & $31-60$ \\
1.80 & 0.11 & 12 & 0.31 & 30 & 22 & 30 & 3 & 110 & 17 & 8.1 & 1.6 & $61-90$ \\
\hline
\end{tabular}


84

Tab. 2. Chemical analysis of the irrigated water

\begin{tabular}{ccccccc}
\hline \multirow{2}{*}{$\mathrm{EC} \mathrm{dS} / \mathrm{m}$} & \multirow{2}{*}{$\mathrm{pH}$} & \multicolumn{5}{c}{ Ions in $\mathrm{mel}^{-1}$} \\
& $\mathrm{HCO}_{3}^{-}$ & $\mathrm{Cl}$ & $\mathrm{SO}_{4}{ }^{-}$ & $\mathrm{Ca}^{++}+\mathrm{Mg}^{++}$ & $\mathrm{Na}^{+}$ \\
\hline 1.4 & 7.9 & 2.6 & 6.5 & 5 & 6 & 8.2 \\
\hline
\end{tabular}

was obtained with the foliar application of $0.80 \% \mathrm{Mg}$ and $0.40 \% \mathrm{Zn}$ solutions. Among the three cultivars, 'Ghezel' produced the highest TSS (Fig. 2). The highest sugar percentage (17.2\%) was obtained with the foliar application of $0.80 \% \mathrm{Mg}$ and $0.40 \% \mathrm{Zn}$ solutions (Fig. 3). Likewise, the main effects of foliar application of $\mathrm{Mg}$ and $\mathrm{Zn}$ were significant at $1 \%$ level in the lowering of $\mathrm{K} / \mathrm{Mg}$ ratio, but

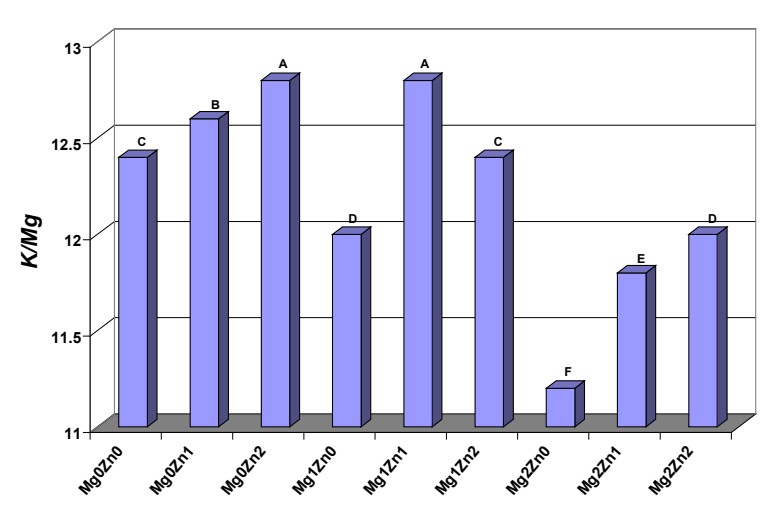

Fig. 4. Effcts of $\mathrm{Mg}$ and $\mathrm{Zn}$ on the ratio of $\mathrm{K} / \mathrm{Mg}$ in grapes

Tab. 3. Effects of different treatments on grape leaf nutrient concentrations

\begin{tabular}{|c|c|c|c|c|c|c|c|c|c|c|}
\hline \multirow{2}{*}{ Treatments } & \multicolumn{5}{|c|}{ Percentage } & \multicolumn{5}{|c|}{$\mathrm{mg} \mathrm{kg}^{-1}$} \\
\hline & $\mathrm{N}$ & $\mathrm{P}$ & $\mathrm{K}$ & $\mathrm{Ca}$ & $\mathrm{Mg}$ & $\mathrm{Fe}$ & $\mathrm{Mn}$ & $\mathrm{Zn}$ & $\mathrm{Cu}$ & $\mathrm{B}$ \\
\hline Mg 0 Zn 0 'Sahebi' & $1.86 \mathrm{~B}$ & $0.24 \mathrm{~A}$ & $1.56 \mathrm{~A}$ & $3.21 \mathrm{AB}$ & $0.42 \mathrm{~A}$ & $46 \mathrm{AB}$ & $39 \mathrm{~A}$ & $8 \mathrm{C}$ & $4.8 \mathrm{~A}$ & $44 \mathrm{~A}$ \\
\hline Mg $0 \mathrm{Zn} 0$ 'Soltani' & $1.97 \mathrm{~B}$ & $0.21 \mathrm{~B}$ & $1.52 \mathrm{~A}$ & $3.20 \mathrm{AB}$ & $0.39 \mathrm{~A}$ & $45 \mathrm{AB}$ & $40 \mathrm{~A}$ & $25 \mathrm{~A}$ & $5.1 \mathrm{~A}$ & $40 \mathrm{C}$ \\
\hline Mg $0 \mathrm{Zn} 0$ 'Ghezel' & $1.87 \mathrm{~B}$ & $0.21 \mathrm{~B}$ & $1.50 \mathrm{~A}$ & $3.33 \mathrm{~A}$ & $0.45 \mathrm{~A}$ & $46 \mathrm{AB}$ & $42 \mathrm{~A}$ & $25 \mathrm{~A}$ & $5.0 \mathrm{~A}$ & $41 \mathrm{~B}$ \\
\hline Mg 0 Zn 1 'Sahebi' & $1.98 \mathrm{~B}$ & $0.25 \mathrm{~A}$ & $1.52 \mathrm{~A}$ & $3.28 \mathrm{AB}$ & $0.42 \mathrm{~B}$ & $45 \mathrm{AB}$ & $40 \mathrm{~A}$ & $10 \mathrm{C}$ & $4.9 \mathrm{~A}$ & $42 \mathrm{~B}$ \\
\hline Mg 0 Zn 1 'Soltani' & $1.96 \mathrm{~B}$ & 0.22 & $1.48 \mathrm{AB}$ & $3.29 \mathrm{AB}$ & $0.45 \mathrm{AB}$ & $40 \mathrm{~B}$ & $42 \mathrm{~A}$ & $15 \mathrm{C}$ & $5.0 \mathrm{~A}$ & $43 \mathrm{~B}$ \\
\hline Mg 0 Zn 1 'Ghezel' & $1.87 \mathrm{~B}$ & $0.20 \mathrm{AB}$ & $1.49 \mathrm{AB}$ & $3.30 \mathrm{AB}$ & $0.43 \mathrm{~B}$ & $42 \mathrm{~B}$ & $40 \mathrm{~A}$ & $27 \mathrm{~A}$ & $5.1 \mathrm{~A}$ & $44 \mathrm{~A}$ \\
\hline Mg 0 Zn 2 'Sahebi' & $1.88 \mathrm{~B}$ & $0.26 \mathrm{~A}$ & $1.51 \mathrm{~A}$ & $3.32 \mathrm{~A}$ & $0.44 \mathrm{AB}$ & $45 \mathrm{AB}$ & $41 \mathrm{~A}$ & $11 \mathrm{C}$ & $5.5 \mathrm{~A}$ & $43 \mathrm{AB}$ \\
\hline Mg 0 Zn 2 'Soltani' & $1.78 \mathrm{~B}$ & $0.22 \mathrm{AB}$ & $1.50 \mathrm{~A}$ & $3.31 \mathrm{AB}$ & $0.45 \mathrm{AB}$ & $47 \mathrm{~A}$ & $42 \mathrm{~A}$ & $17 \mathrm{C}$ & $5.2 \mathrm{~A}$ & $42 \mathrm{AB}$ \\
\hline Mg $0 \mathrm{Zn} 2$ 'Ghezel' & $1.82 \mathrm{~B}$ & $0.20 \mathrm{~B}$ & $1.49 \mathrm{~A}$ & $3.30 \mathrm{AB}$ & $0.43 \mathrm{~B}$ & $48 \mathrm{~A}$ & $41 \mathrm{~A}$ & $26 \mathrm{~A}$ & $4.9 \mathrm{~A}$ & $41 \mathrm{AB}$ \\
\hline Mg 1 Zn 0 'Sahebi' & $2.10 \mathrm{~A}$ & $0.24 \mathrm{~A}$ & $1.48 \mathrm{AB}$ & $3.66 \mathrm{~A}$ & $0.45 \mathrm{AB}$ & $45 \mathrm{AB}$ & $39 \mathrm{~A}$ & $14 \mathrm{C}$ & $4.8 \mathrm{~A}$ & $40 \mathrm{BC}$ \\
\hline Mg 1 Zn 0 'Soltani' & $2.15 \mathrm{~A}$ & $0.21 \mathrm{~B}$ & $1.47 \mathrm{AB}$ & $3.52 \mathrm{~A}$ & $0.44 \mathrm{AB}$ & $47 \mathrm{~A}$ & $40 \mathrm{~A}$ & $21 \mathrm{~B}$ & $4.7 \mathrm{~A}$ & $41 B C$ \\
\hline Mg $1 \mathrm{Zn} 0$ 'Ghezel' & $2.12 \mathrm{~A}$ & $0.19 \mathrm{~B}$ & $1.49 \mathrm{~A}$ & $3.48 \mathrm{~A}$ & $0.43 \mathrm{~B}$ & $48 \mathrm{~A}$ & $42 \mathrm{~A}$ & $27 \mathrm{~A}$ & $4.6 \mathrm{~A}$ & $41 B$ \\
\hline Mg 1 Zn 1 'Sahebi' & $2.15 \mathrm{~A}$ & $0.23 \mathrm{~A}$ & $1.44 \mathrm{~B}$ & $3.36 \mathrm{~A}$ & $0.42 \mathrm{~B}$ & $46 \mathrm{AB}$ & $41 \mathrm{~A}$ & $13 \mathrm{C}$ & $4.5 \mathrm{~A}$ & $42 \mathrm{AB}$ \\
\hline Mg 1 Zn 1 'Soltani' & $2.17 \mathrm{~A}$ & $0.21 \mathrm{AB}$ & $1.45 \mathrm{~B}$ & $3.42 \mathrm{~A}$ & $0.45 \mathrm{AB}$ & $45 \mathrm{AB}$ & $41 \mathrm{~A}$ & $19 \mathrm{~B}$ & $4.7 \mathrm{~A}$ & $41 \mathrm{AB}$ \\
\hline Mg 1 Zn 1 'Ghezel' & $2.19 \mathrm{~A}$ & $0.20 \mathrm{AB}$ & $1.42 \mathrm{~B}$ & $3.50 \mathrm{~A}$ & $0.43 \mathrm{~B}$ & $46 \mathrm{~A}$ & $42 \mathrm{~A}$ & 24 & $4.9 \mathrm{~A}$ & $43 \mathrm{AB}$ \\
\hline Mg 1 Zn 2 'Sahebi' & $2.11 \mathrm{~A}$ & $0.24 \mathrm{~A}$ & $1.43 \mathrm{~B}$ & $3.52 \mathrm{~A}$ & $0.42 \mathrm{~B}$ & $47 \mathrm{~A}$ & $41 \mathrm{~A}$ & $14 \mathrm{C}$ & $4.6 \mathrm{~A}$ & $40 \mathrm{~A}$ \\
\hline Mg 1 Zn 2 'Soltani' & $2.12 \mathrm{~A}$ & $0.23 \mathrm{~A}$ & $1.43 \mathrm{~B}$ & $3.60 \mathrm{~A}$ & $0.45 \mathrm{AB}$ & $46 \mathrm{~A}$ & $39 \mathrm{~A}$ & $21 \mathrm{~B}$ & $4.7 \mathrm{~A}$ & $41 \mathrm{~B}$ \\
\hline Mg $1 \mathrm{Zn} 2$ 'Ghezel' & $2.18 \mathrm{~A}$ & $0.22 \mathrm{AB}$ & $1.42 \mathrm{~B}$ & $3.50 \mathrm{~A}$ & $0.44 \mathrm{AB}$ & $45 \mathrm{AB}$ & $40 \mathrm{~A}$ & $29 \mathrm{~A}$ & $4.8 \mathrm{~A}$ & $42 \mathrm{AB}$ \\
\hline Mg 2 Zn 0 'Sahebi' & $2.15 \mathrm{~A}$ & $0.21 \mathrm{AB}$ & $1.45 \mathrm{~B}$ & $3 \mathrm{~B}$ & $0.46 \mathrm{~A}$ & $44 \mathrm{~B}$ & $44 \mathrm{~A}$ & $18 \mathrm{C}$ & $4.5 \mathrm{~A}$ & $43 \mathrm{AB}$ \\
\hline Mg 2 Zn 0 'Soltani’ & $2.21 \mathrm{~A}$ & $0.22 \mathrm{~A}$ & $1.41 \mathrm{~B}$ & $3 \mathrm{~B}$ & $0.48 \mathrm{~A}$ & $43 \mathrm{~B}$ & $40 \mathrm{~A}$ & $17 \mathrm{C}$ & $4.4 \mathrm{~A}$ & $44 \mathrm{~A}$ \\
\hline Mg 2 Zn 0 'Ghezel' & $2.23 \mathrm{~A}$ & $0.23 \mathrm{~A}$ & $1.42 \mathrm{~B}$ & $2.6 \mathrm{~B}$ & $0.48 \mathrm{~A}$ & $42 \mathrm{~B}$ & $45 \mathrm{~A}$ & $17 \mathrm{C}$ & $4.3 \mathrm{~A}$ & $41 \mathrm{~B}$ \\
\hline Mg 2 Zn 1 'Sahebi' & $2.14 \mathrm{~A}$ & $0.25 \mathrm{~A}$ & $1.43 \mathrm{~B}$ & $2.5 \mathrm{~B}$ & $0.49 \mathrm{~A}$ & $43 \mathrm{~B}$ & $43 \mathrm{~A}$ & $19 \mathrm{~B}$ & $4.2 \mathrm{~A}$ & $42 \mathrm{AB}$ \\
\hline Mg 2 Zn 1 'Soltani' & $2.18 \mathrm{~A}$ & $0.24 \mathrm{~A}$ & $1.45 \mathrm{~B}$ & $2.6 \mathrm{~B}$ & $0.48 \mathrm{~A}$ & $42 \mathrm{~B}$ & $42 \mathrm{~A}$ & $19 \mathrm{~B}$ & $4.1 \mathrm{~A}$ & $42 \mathrm{AB}$ \\
\hline Mg 2 Zn 1 'Ghezel’ & $2.18 \mathrm{~A}$ & $0.23 \mathrm{~A}$ & $1.46 \mathrm{~B}$ & $2.5 \mathrm{~B}$ & $0.51 \mathrm{AQ}$ & $43 \mathrm{~B}$ & $41 \mathrm{~A}$ & $25 \mathrm{~A}$ & $4.2 \mathrm{~A}$ & $43 \mathrm{AB}$ \\
\hline Mg 2 Zn 2 'Sahebi' & $2.25 \mathrm{~A}$ & $0.21 \mathrm{AB}$ & $1.42 \mathrm{~B}$ & $2.5 \mathrm{~B}$ & $0.5 \mathrm{~A}$ & $43 \mathrm{~B}$ & $42 \mathrm{~A}$ & $24 \mathrm{~A}$ & $4.3 \mathrm{~A}$ & $42 \mathrm{AB}$ \\
\hline Mg 2 Zn 2 'Soltani' & $2.24 \mathrm{~A}$ & $0.22 \mathrm{~A}$ & $1.43 \mathrm{~B}$ & $2.5 \mathrm{~B}$ & $0.5 \mathrm{~A}$ & $42 \mathrm{~B}$ & $44 \mathrm{~A}$ & $25 \mathrm{~A}$ & $4.2 \mathrm{~A}$ & $42 \mathrm{AB}$ \\
\hline Mg 2 Zn 2'Ghezel' & $2.21 \mathrm{~A}$ & $0.23 \mathrm{~A}$ & $1.41 \mathrm{~B}$ & $2.4 \mathrm{~B}$ & $0.51 \mathrm{~A}$ & $43 \mathrm{~B}$ & $43 \mathrm{~A}$ & $24 \mathrm{~A}$ & $4.3 \mathrm{~A}$ & $41 \mathrm{~B}$ \\
\hline
\end{tabular}

The average values that are followed by the same letters are significantly the same at $5 \%$ level (as tested by multi range Duncan test)

still this ratio was much more than desirable level (5.0-7.0) for the studied cultivars (Fig. 4).

\section{Conclusions}

Results obtained from the experiments indicated that with the increase in the amount of $\mathrm{Mg}$ application, the leaf chlorophyll content and hence photosynthesis level was increased, contributing to a significant increase in the percentages of soluble solids and dry matter. The increase of $\mathrm{Mg}$ in chloroplasts had a positive effect on the absorption of $\mathrm{K}$. Leaves with higher content of $\mathrm{Mg}$ absorb more $\mathrm{K}$, which contributed to a significant increase in the grape sugar (Mg has a significant role in the formation of ATP and transfer of energy, thereby, facilitating sugar synthesis in the grape fruit. $\mathrm{Mg}$, much similar to $\mathrm{Zn}$, increases the 
Tab. 4. Effects of various treatments on dried grape (raisin) concentrations

\begin{tabular}{|c|c|c|c|c|c|c|c|c|c|c|}
\hline \multirow{2}{*}{ Treatments } & \multicolumn{5}{|c|}{ Percentage } & \multicolumn{5}{|c|}{$\mathrm{mg} \mathrm{kg}^{-1}$} \\
\hline & $\mathrm{N}$ & $\mathrm{P}$ & $\mathrm{K}$ & $\mathrm{Ca}$ & $\mathrm{Mg}$ & $\mathrm{Fe}$ & $\mathrm{Mn}$ & $\mathrm{Zn}$ & $\mathrm{Cu}$ & B \\
\hline Mg 0 Zn 0 'Sahebi' & $1.06 \mathrm{~B}$ & $0.08 \mathrm{~A}$ & $0.56 \mathrm{~A}$ & $0.21 \mathrm{AB}$ & $0.02 \mathrm{~B}$ & $56 \mathrm{AB}$ & $8 \mathrm{~A}$ & $8 \mathrm{~B}$ & $2.8 \mathrm{~A}$ & $24 \mathrm{~A}$ \\
\hline Mg 0 Zn 0 'Soltani' & $1.07 \mathrm{~B}$ & $0.01 \mathrm{~B}$ & $0.52 \mathrm{~A}$ & $0.20 \mathrm{AB}$ & $0.09 \mathrm{~A}$ & $55 \mathrm{AB}$ & $8 \mathrm{~A}$ & $7 \mathrm{C}$ & $2.1 \mathrm{~A}$ & $20 \mathrm{C}$ \\
\hline Mg $0 \mathrm{Zn} 0$ 'Ghezel' & $1.17 \mathrm{~B}$ & $0.01 \mathrm{~B}$ & $0.50 \mathrm{~A}$ & $0.63 \mathrm{~A}$ & $0.05 \mathrm{AB}$ & $56 \mathrm{AB}$ & $8 \mathrm{~A}$ & $7 \mathrm{C}$ & $2.0 \mathrm{~A}$ & $21 \mathrm{~B}$ \\
\hline Mg 0 Zn 1 'Sahebi' & $1.08 \mathrm{~B}$ & $0.09 \mathrm{~A}$ & $0.52 \mathrm{~A}$ & $0.48 \mathrm{AB}$ & $0.02 \mathrm{~B}$ & $55 \mathrm{AB}$ & $8 \mathrm{~A}$ & $7 \mathrm{C}$ & $2.9 \mathrm{~A}$ & $22 \mathrm{~B}$ \\
\hline Mg 0 Zn1'Soltani' & $1.06 \mathrm{~B}$ & $0.02 \mathrm{~B}$ & $0.48 \mathrm{AB}$ & $0.49 \mathrm{AB}$ & $0.05 \mathrm{AB}$ & $50 \mathrm{~B}$ & $8 \mathrm{~A}$ & $7 \mathrm{C}$ & $2.0 \mathrm{~A}$ & $23 \mathrm{AB}$ \\
\hline Mg 0 Zn 1 'Ghezel' & $1.07 \mathrm{~B}$ & $0.02 \mathrm{~B}$ & $0.49 \mathrm{AB}$ & $0.40 \mathrm{AB}$ & $0.03 \mathrm{~B}$ & $52 \mathrm{~B}$ & $8 \mathrm{~A}$ & $7 \mathrm{C}$ & $2.1 \mathrm{~A}$ & $24 \mathrm{~A}$ \\
\hline Mg 0 Zn 2 'Sahebi' & $1.08 \mathrm{~B}$ & $0.06 \mathrm{~A}$ & $0.51 \mathrm{~A}$ & $0.52 \mathrm{~A}$ & $0.04 \mathrm{AB}$ & $55 \mathrm{AB}$ & $8 \mathrm{~A}$ & $8 \mathrm{~B}$ & $2.5 \mathrm{~A}$ & $23 \mathrm{AB}$ \\
\hline Mg 0 Zn 2 'Soltani' & $1.08 \mathrm{~B}$ & $0.02 \mathrm{~B}$ & $0.50 \mathrm{~A}$ & $0.51 \mathrm{AB}$ & $0.05 \mathrm{AB}$ & $57 \mathrm{~A}$ & $8 \mathrm{~A}$ & $8 \mathrm{~B}$ & $2.2 \mathrm{~A}$ & $22 \mathrm{~B}$ \\
\hline Mg 0 Zn 2 'Ghezel' & $1.02 \mathrm{~B}$ & $0.02 \mathrm{~B}$ & $0.49 \mathrm{AB}$ & $0.50 \mathrm{AB}$ & $0.03 \mathrm{~B}$ & $58 \mathrm{~A}$ & $8 \mathrm{~A}$ & $9 \mathrm{~A}$ & $2.9 \mathrm{~A}$ & $21 \mathrm{BC}$ \\
\hline Mg 1 Zn 0 'Sahebi' & $1.00 \mathrm{~A}$ & $0.08 \mathrm{~A}$ & $0.48 \mathrm{AB}$ & $0.66 \mathrm{~A}$ & $0.05 \mathrm{AB}$ & $55 \mathrm{AB}$ & $8 \mathrm{~A}$ & $7 \mathrm{C}$ & $2.8 \mathrm{~A}$ & $20 \mathrm{C}$ \\
\hline Mg 1 Zn 0 'Soltani' & $1.15 \mathrm{~A}$ & $0.01 \mathrm{~B}$ & $0.47 \mathrm{AB}$ & $0.62 \mathrm{~A}$ & $0.04 \mathrm{AB}$ & $57 \mathrm{~A}$ & $9 \mathrm{~A}$ & $7 \mathrm{C}$ & $2.7 \mathrm{~A}$ & $21 B C$ \\
\hline Mg 1 Zn 0 'Ghezel' & $1.12 \mathrm{~A}$ & $0.04 \mathrm{~B}$ & $0.49 \mathrm{AB}$ & $0.68 \mathrm{~A}$ & $0.03 \mathrm{~B}$ & $58 \mathrm{~A}$ & $9 \mathrm{~A}$ & $7 \mathrm{C}$ & $2.6 \mathrm{~A}$ & $21 \mathrm{~B}$ \\
\hline Mg 1 Zn 1 'Sahebi' & $1.15 \mathrm{~A}$ & $0.08 \mathrm{~A}$ & $0.44 \mathrm{~B}$ & $0.66 \mathrm{~A}$ & $0.02 \mathrm{~B}$ & $56 \mathrm{AB}$ & $9 \mathrm{~A}$ & $8 \mathrm{~B}$ & $2.5 \mathrm{~A}$ & $22 \mathrm{~B}$ \\
\hline Mg 1 Zn 1 'Soltani' & $1.10 \mathrm{~A}$ & $0.06 \mathrm{AB}$ & $0.45 \mathrm{~B}$ & $0.62 \mathrm{~A}$ & $0.05 \mathrm{AB}$ & $55 \mathrm{AB}$ & $9 \mathrm{~A}$ & $8 \mathrm{~B}$ & $2.7 \mathrm{~A}$ & $21 \mathrm{BC}$ \\
\hline Mg $1 \mathrm{Zn} 1$ 'Ghezel' & $1.10 \mathrm{~A}$ & $0.07 \mathrm{AB}$ & $0.42 \mathrm{~B}$ & $0.60 \mathrm{~A}$ & $0.03 \mathrm{~B}$ & $56 \mathrm{AB}$ & $9 \mathrm{~A}$ & $8 \mathrm{~B}$ & $2.9 \mathrm{~A}$ & $23 \mathrm{AB}$ \\
\hline Mg 1 Zn 2 'Sahebi' & $1.11 \mathrm{~A}$ & $0.09 \mathrm{~A}$ & $0.43 \mathrm{~B}$ & $0.62 \mathrm{~A}$ & $0.02 \mathrm{~B}$ & $57 \mathrm{~A}$ & $9 \mathrm{~A}$ & $9 \mathrm{~A}$ & $2.6 \mathrm{~A}$ & $20 \mathrm{C}$ \\
\hline Mg 1 Zn 2 'Soltani' & $1.12 \mathrm{~A}$ & $0.09 \mathrm{~A}$ & $0.43 \mathrm{~B}$ & $0.60 \mathrm{~A}$ & $0.05 \mathrm{AB}$ & $56 \mathrm{~A}$ & $9 \mathrm{~A}$ & $9 \mathrm{~A}$ & $2.7 \mathrm{~A}$ & $21 \mathrm{BC}$ \\
\hline Mg $1 \mathrm{Zn} 2$ 'Ghezel' & $1.10 \mathrm{~A}$ & $0.05 \mathrm{AB}$ & $0.42 \mathrm{~B}$ & $0.60 \mathrm{~A}$ & $0.04 \mathrm{AB}$ & $55 \mathrm{AB}$ & $9 \mathrm{~A}$ & $10 \mathrm{~A}$ & $2.8 \mathrm{~A}$ & $22 \mathrm{~B}$ \\
\hline Mg 2 Zn 0 'Sahebi’ & $1.15 \mathrm{~A}$ & $0.05 \mathrm{AB}$ & $0.45 \mathrm{~B}$ & $0.42 \mathrm{~B}$ & $0.06 \mathrm{~A}$ & $54 \mathrm{~B}$ & $8 \mathrm{~A}$ & $7 \mathrm{C}$ & $2.5 \mathrm{~A}$ & $23 \mathrm{AB}$ \\
\hline Mg 2 Zn 0 'Soltani' & $1.21 \mathrm{~A}$ & $0.09 \mathrm{~A}$ & $0.41 \mathrm{~B}$ & $0.51 \mathrm{AB}$ & $0.08 \mathrm{~A}$ & $53 \mathrm{~B}$ & $8 \mathrm{~A}$ & $7 \mathrm{C}$ & $2.4 \mathrm{~A}$ & $24 \mathrm{~A}$ \\
\hline Mg 2 Zn 0 'Ghezel' & $1.23 \mathrm{~A}$ & $0.09 \mathrm{~A}$ & $0.42 \mathrm{~B}$ & $0.6 \mathrm{~B}$ & $0.08 \mathrm{~A}$ & $52 \mathrm{~B}$ & $8 \mathrm{~A}$ & $7 \mathrm{C}$ & $2.3 \mathrm{~A}$ & $21 \mathrm{BC}$ \\
\hline Mg 2 Zn 1 'Sahebi' & $1.14 \mathrm{~A}$ & $0.09 \mathrm{~A}$ & $0.43 \mathrm{~B}$ & $0.5 \mathrm{~B}$ & $0.09 \mathrm{~A}$ & $53 \mathrm{~B}$ & $8 \mathrm{~A}$ & $8 \mathrm{~B}$ & $2.2 \mathrm{~A}$ & $22 \mathrm{~B}$ \\
\hline Mg 2 Zn 1 'Soltani' & $1.18 \mathrm{~A}$ & $0.08 \mathrm{~A}$ & $0.45 \mathrm{~B}$ & $0.6 \mathrm{~B}$ & $0.08 \mathrm{~A}$ & $52 \mathrm{~B}$ & $9 \mathrm{~A}$ & $8 \mathrm{~B}$ & $2.1 \mathrm{~A}$ & $22 \mathrm{AB}$ \\
\hline Mg 2 Zn 1 'Ghezel' & $1.18 \mathrm{~A}$ & $0.08 \mathrm{~A}$ & $0.46 \mathrm{~B}$ & $0.5 \mathrm{~B}$ & $0.01 \mathrm{~B}$ & $53 \mathrm{~B}$ & $9 \mathrm{~A}$ & $8 \mathrm{~B}$ & $2.2 \mathrm{~A}$ & $23 \mathrm{AB}$ \\
\hline Mg 2 Zn 2 'Sahebi’ & $1.05 \mathrm{~A}$ & $0.06 \mathrm{AB}$ & $0.42 \mathrm{~B}$ & $0.5 \mathrm{~B}$ & $0.1 \mathrm{~A}$ & $53 \mathrm{~B}$ & $8 \mathrm{~A}$ & $9 \mathrm{~A}$ & $2.3 \mathrm{~A}$ & $22 \mathrm{~B}$ \\
\hline Mg 2 Zn 2 'Soltani' & $1.04 \mathrm{~A}$ & $0.07 \mathrm{AB}$ & $0.43 \mathrm{~B}$ & $0.5 \mathrm{~B}$ & $0.1 \mathrm{~A}$ & $52 \mathrm{~B}$ & $8 \mathrm{~A}$ & $9 \mathrm{~A}$ & $2.2 \mathrm{~A}$ & $22 \mathrm{~B}$ \\
\hline Mg 2 Zn 2 'Ghezel' & $1.01 \mathrm{~A}$ & $0.08 \mathrm{~A}$ & $0.41 \mathrm{~B}$ & $0.4 \mathrm{~B}$ & $0.1 \mathrm{~A}$ & $53 \mathrm{~B}$ & $9 \mathrm{~A}$ & $10 \mathrm{~A}$ & $2.3 \mathrm{~A}$ & $21 \mathrm{BC}$ \\
\hline
\end{tabular}

* The average values that are followed by the same letters are significantly the same at $5 \%$ level (as tested by multi range Duncan test)

enzymatic activities of fructose-1 and 6- bis phosphatase, causing increased sugar synthesis in the grape). In view to the fact that the levels of $\mathrm{Mg}$ in the soils where the experiments have been conducted are low, the foliar application of $\mathrm{Mg}$ solution has increased the translocation of synthesized materials of the photosynthesis from the leaf to the grape fruit (Malakouti, 2006).

With the increase in the amount of $\mathrm{Zn}$ applied, the sugar content in the three grape cultivars increased significantly, which is a possible result of the increase in the enzymatic activities of fructose- 1 and 6 - bis phosphatase. On the other hand, the aldolase enzymes will increase along with the sufficient availability of $\mathrm{Zn}$, contributing to an accelerated sugar synthesis. With the increase in the concentration of $\mathrm{Zn}$ in leaves of the grape cultivars tested, the level of carbonic anhydridease and net photosynthesis were increased and contributed to an increase in the level of solids content in the syrup obtained from the grapes. With the increase of $\mathrm{Zn}$ levels, the amount of $\mathrm{P}$ in the leaves of the three grape cultivars decreased, which is mainly due to dilution and their antagonistic effects. $\mathrm{Zn}$, in a probable reaction with R-SH group of the membrane proteins, causes the membrane firmness in cultivars with high zinc contents, thereby significantly improving their storability characteristics, which correspond with the findings of Marschner (1995) and Malakouti (2006).

Statistical analysis indicated that, in addition to yield increase, the concentration of $\mathrm{Mg}$ and $\mathrm{Zn}$ in grapes had significantly increased with treatments, which corresponds with the findings of Malakouti et al. (2004). Changing the conventional fertilization practices of grape growers (mostly N, P and sometimes K-fertilizers) is very difficult and time consuming and the cost of $\mathrm{Mg}$ and $\mathrm{Zn}$ sulphate is very high (The fertilizer subsidy is given only to $\mathrm{N}, \mathrm{P}$, and K-fertilizers). Therefore, currently, due to economic reasons, the foliar application of $\mathrm{Mg}$ and $\mathrm{Zn}$-fertilizers is an appropriate method. Besides, by foliar application, in addition to yield increase, the quality of grapes, especially the sugar percentage, $\mathrm{Mg}$ and $\mathrm{Zn}$ concentrations in the grape increased, which is important for human health promotion. However, by the foliar application of magnesium sulphate, we could not obtain an appropriate $\mathrm{K} / \mathrm{Mg}$ ratio (5.0-7.0), which means foliar application of $\mathrm{Mg}$ solution by itself was not enough to decrease $\mathrm{K} / \mathrm{Mg}$ ratio. Therefore, combination of soil and foliar applications are to be recommended. In other words, soil and foliar applications 
86

of magnesium sulphate is necessary for lowering $\mathrm{K} / \mathrm{Mg}$ ratio in deficient soils.

\section{References}

Havlin, J. L., J. D. Beaton, S. L. Tisdale and W. L. Nelson (2005) Soil fertility and fertilizers: An introduction to nutrient management. $7^{\text {th }}$ edition. Pearson Prentice Hall. Upper Saddle River, New Jersey. USA.

Kali, G. (2002). ESTA Kieserite, A product of nature. Agricultural Advisory Department, $\mathrm{K}+\mathrm{S}$ Kali GmbH.

Malakouti, M. J. (2006). Nutritional disorders in fruit trees on the calcareous soils of Iran. Proceedings of the $18^{\text {th }}$ World Congress of Soil Science: Frontiers of Soil science Technology and the Information Age. Philadelphia, Pennsylvania, USA.

Malakouti, M. J. (2007). Zinc is a neglected element in the life cycle of plants: A review. Middle Eastern and Russian Journal of Plant Science and Biotechnology 1:1-12.
Malakouti, M. J. and H. Rezaei (2001). The roles of sulphur, calcium and magnesium on the improvement of yield and quality of agricultural products. Ministry of Agriculture. Tehran, Iran.

Malakouti, M. J., A. A. Shahabi and K. Bazargan(2005). Potassium in Iranian agriculture. Sana Publication Co., Ministry of Jihad-e-Agriculture. Tehran, Iran.

Marschner, H. (1995). Mineral nutrition of higher plants. $2^{\text {nd }}$ Ed. Academic Press. New York.

Mengel, K. and E. A. Kirkby(1987). Principles of plant nutrition. International Potash Institute. Bern, Switzerland.

Shahabi, A. A., M. J. Malakouti and E. Fallahi (2005). Effects of bicarbonate content of irrigation water on nutritional disorders of some apple varieties. Journal of Plant Nutrition. 28:1663-1678. 